\title{
Predation on the lizard Polychrus acutirostris (Squamata, Polychrotidae) by the curl-crested jay Cyanocorax cristatellus (Aves, Corvidae) in the Cerrado of Central Brazil
}

\author{
Frederico Gustavo Rodrigues França* \\ Vívian da Silva Braz \\ Departamento de Zoologia, Instituto de Biologia, Universidade de Brasília \\ CEP 70910-900, Brasília - DF, Brazil \\ *Author for correspondence \\ fgrf@unb.br
}

Submitted in 24/10/2008 Accepted for publication in 29/04/2009

\section{Resumo}

Predação do lagarto Polychrus acutirostris (Squamata, Polychrotidae) pela gralha-do-campo Cyanocorax cristatellus (Aves, Corvidae) no Cerrado do Brasil Central. Eventos de predação em lagartos são difíceis de observar na natureza. Aqui é apresentado o primeiro evento de predação do lagarto Polychrus acutirostris pela gralha-do-campo Cyanocorax cristatellus em uma área de cerrado do Parque Nacional da Chapada dos Veadeiros - GO, aumentando o conhecimento dos hábitos alimentares desta espécie de ave.

Unitermos: Cyanocorax cristatellus, Polychrus acutirostris, predação

\section{Abstract}

Predation on lizards is difficult to observe in nature. Here, we report for the first time an act of predation on the lizard Polychrus acutirostris by the Curl-crested Jay Cyanocorax cristatellus in a Cerrado area of the Chapada dos Veadeiros National Park, central Brazil, thus increasing knowledge of the diet of this bird species.

Key words: Cyanocorax cristatellus, Polychrus acutirostris, predation

Lizards are recognized as bird prey in Neotropical habitats (Rocha and Vrcibradic, 1998; Pianka and Vitt, 2003). Generally, birds that eat lizards are large nonpasserine species such as raptors, owls, seriemas and motmots, but such predation by Passeriforme species is very infrequent (del Hoyo et al., 1994; 1999; Sick, 1997). The Curl-crested Jay (Cyanocorax cristatellus) is a large Oscine passerine (mean adult size $=34.5 \mathrm{~cm}$ ) distributed in open areas of Brazil, Paraguay and Bolivia, and it is considered to be endemic to the Cerrado biome (Ridgely and Tudor, 1989; Sick, 1997). The diet of this species includes insects (termites, orthopterans and wasp nests), fruits and nectar (Henriques and Palma, 1998; Amaral and Macedo, 2003). Here, we report the first observation of a Curl-crested Jay preying on the lizard Polycrus acutirostris (Polychrotidae) in the Cerrado of central Brazil. 
The observation occurred on 25 August 2006 at $11: 20 \mathrm{~h}$ during field work on a canyon waterfalls of the Chapada dos Veadeiros National Park (140'의, $47^{\circ} 48^{\prime} \mathrm{W}$; elev. 1092m), municipality of Alto Paraíso, state of Goiás. We witnessed a single Curl-crested Jay jumping between the branches of a Cerrado sensu-stricto tree carrying a Polychrus acutirostris (snout-vent length $=130 \mathrm{~mm}$, approximately) in its bill (Figure 1A). The lizard was identified visually due to its characteristic morphology and coloration. Afterwards, the jay flew up to a higher branch and held the lizard on it with its the claws (Figure 1B). The jay pecked several times exclusively on the lizard's head and then proceeded to swallow it by the injured head, taking up to half an hour to ingest the lizard entirely.

Polychrus acutirostris is a medium-sized $(<150 \mathrm{~mm}$ SVL) arboreal lizard that inhabits open formations of South America, east of the Andes (Ávila-Pires, 1995). This lizard exhibits some tactics to escape predation. To avoid detection it can remain motionless like a branch, and can change its dorsal pigmentation to match the background. When detected, it shows a threatening behaviour, filling the lungs and expanding the body, and mostly it opens its mouth to show the black coloration inside (Vanzolini et al., 1980; Vitt and Lacher, 1981). Although some snakes (Chironius multiventris, Rhinobothrium lentiginosum, and Siphlophis cervinus) have been observed preying on Polychrus species (Martins and Oliveira, 1999), there is no record of bird predation for this genus. The predation behavior presented by the jay, pecking the lizard's head first, indicates that this bird recognizes $P$. acutirostris as a dangerous species. This behavior is commonly used by birds that prey on venomous snakes such as vipers and rattlesnakes (Greene, 1997).

The family Corvidae is recognized in the literature as comprising mainly omnivorous species, feeding on invertebrates, fruits, reptiles, amphibians, small birds and mammals, and carrion, as well as eggs (Goodwin, 1986; Zusi, 1987). The diet of another two Brazilian jay species, the White-naiped Jay Cyanocorax cyanopogon and the Azure Jay C. caeruleus, indicates that the food items range from vegetable material and invertebrates to bird eggs and young (Reinert and Bornschein, 1998;
Caten et al., 2007), but no lizards or reptiles have been reported. This work reports a newly-discovered food item for Cyanocorax species.

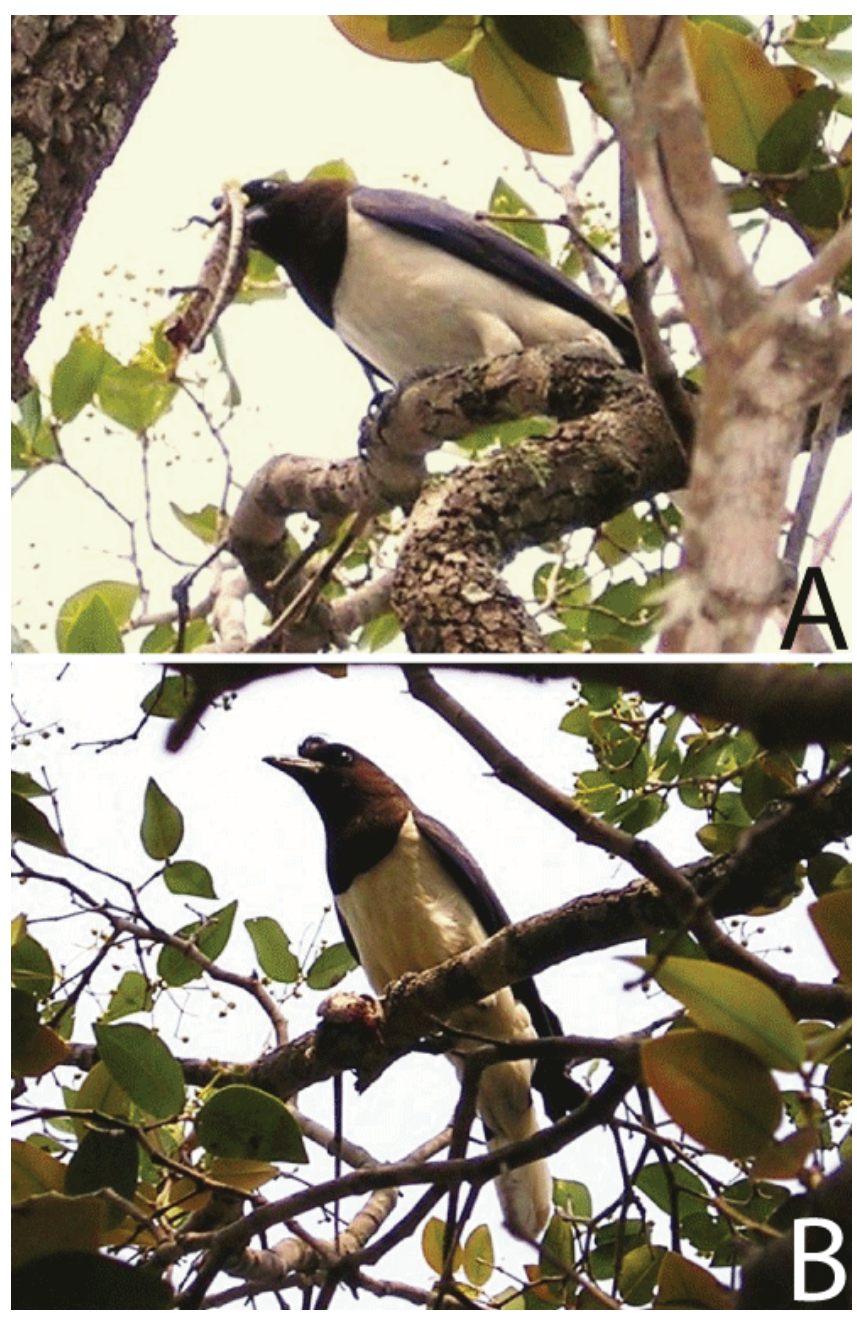

FIGURE 1: A - Cyanocorax cristatellus carrying a Polychrus acutirostris in its bill. B - Cyanocorax cristatellus with the lizard in its claws.

\section{Acknowledgements}

The authors are grateful to Daniel Rios Borges for permission to work in the Parque Nacional da Chapada dos Veadeiros, to Gregory Williams and Viviane Braz for help with the English, and an anonymous reviewer for insightful criticisms on the manuscript.

\section{References}

Amaral, M. F.; Macedo, R. H. F. 2003. Breeding patterns and habitat use in the endemic Curl-crested Jay of central Brazil. Journal of Field Ornithology, 74 (4): 331-340. 
Ávila-Pires, T. C. S. 1995. Lizards of Brazilian Amazonia (Reptilia: Squamata). Zoologische Verhandelingen, 299: 3-706.

Caten, H. T.; Oliveira, J. P. F.; Pascotto, M. C. 2007. Alimentação de Cyanocorax cyanopogon (Corvidae, Passeriformes, Aves) em uma área de Cerrado na Região Leste de Mato Grosso. Anais do VIII Congresso de Ecologia do Brasil, Caxambu, Brasil, Resumo 653.

del Hoyo, J.; Elliot, A.; Sargatal, J. 1994. Handbook of the birds of the world. Volume 2: New World Vultures to Guineafowl. Lynx Edicions, Barcelona, Spain, 638pp.

del Hoyo, J., Elliot, A.; Sargatal, J. 1999. Handbook of the birds of the world. Volume 5: Barn-Owls to Hummingbirds. Lynx Edicions, Barcelona, Spain, 759pp.

Goodwin, D. 1986. Crows of the world. University of Washington Press, Washington, USA, 299pp.

Greene, H. W. 1997. Snakes: The evolution of mystery in nature. University of California Press, California, USA, 351pp.

Henriques, R. P. B.; Palma, A. R. T. 1998. Bird predation on nest of a social wasp in Brazilian cerrado. Revista Biologia Tropical, 46: $1145-1146$.

Martins, M.; Oliveira, M. E. 1998. Natural history of snakes in forests of the Manaus region, Central Amazonia, Brazil. Herpetological Natural History, 6 (2): 78-150.
Pianka, E. R.; Vitt, L. J. 2003. Lizards: Windows to the evolution of diversity. University of California Press, Berkeley, USA, 346pp.

Reinert, B. L.; Bornschein, M. R. 1998. Alimentação da gralhaazul (Cyanocorax caeruleus, Corvidae). Ornitologia Neotropical, 9 (2): 213-217.

Ridgely, R. S.; Tudor, G. 1989. The Birds of South America, v. 1: The Oscine passerines. University of Texas Press, Austin, USA, 516pp.

Rocha, C. F. D.; Vrcibradic, D. 1998. Reptiles as predators of vertebrates and as preys in a restinga habitat of southeastern Brazil. Ciência e Cultura, 50 (5): 364-368.

Sick, H. 1997. Ornitologia Brasileira. Editora Nova Fronteira, Rio de Janeiro, Brasil, 193pp.

Vanzolini, P. E.; Ramos-Costa, A. M. M.; Vitt, L. J. 1980. Répteis das caatingas. Academia Brasileira de Ciências, Rio de Janeiro, Brasil, 161pp.

Vitt, L. J.; Lacher, T. E., Jr. 1981. Behaviour, habitat, diet, and reproduction of the iguanid lizard Polychrus acutirostris in the Caatinga of Northeastern Brazil. Herpetologica, 37 (1): 53-63.

Zusi, R. L. 1987. A feeding adaptation of the jaw articulation in new world jays (Corvidae). The Auk, 104 (4): 665-680. 